\title{
Nineteenth and twentieth century sea-level changes in Tasmania and New Zealand
}

\author{
W. Roland Gehrels ${ }^{\mathrm{a}, *}$, S. Louise Callard ${ }^{\mathrm{b}}$, Patrick T. Moss ${ }^{\mathrm{c}}$, William A. Marshall ${ }^{\text {a }}$, Maarten Blaauw ${ }^{\mathrm{d}}$, \\ John Hunter ${ }^{\mathrm{e}}$, J. Andrew Milton ${ }^{\mathrm{f}}$, Mark H. Garnett ${ }^{\mathrm{g}}$ \\ a School of Geography, Earth E' Environmental Sciences, University of Plymouth, Plymouth, United Kingdom \\ b School of Geography, Environment E' Earth Sciences, Victoria University of Wellington, New Zealand \\ ' School of Geography, Planning E' Environmental Management, University of Queensland; Brisbane, Australia \\ ' School of Geography, Archaeology and Palaeoecology, Queen's University Belfast, Belfast, United Kingdom \\ e Antarctic Climate E' Ecosystems Cooperative Research Centre, University of Tasmania, Hobart, Tasmania, Australia \\ ${ }^{\mathrm{f}}$ National Oceanography Centre, Southampton, and School of Ocean and Earth Science, University of Southampton, United Kingdom \\ ${ }^{g}$ NERC Radiocarbon Facility, East Kilbride, Glasgow, United Kingdom
}

\section{A R T I C L E I N F O}

\section{Article history}

Accepted 31 August 2011

Available online 5 October 2011

Editor P. DeMenocal

\section{Keywords:}

salt marsh

proxy data

foraminifera

Holocene

Anthropocene

Southwest Pacific

\begin{abstract}
A B S T R A C T
Positive deviations from linear sea-level trends represent important climate signals if they are persistent and geographically widespread. This paper documents rapid sea-level rise reconstructed from sedimentary records obtained from salt marshes in the Southwest Pacific region (Tasmania and New Zealand). A new late Holocene relative sea-level record from eastern Tasmania was dated by $\mathrm{AMS}^{14} \mathrm{C}$ (conventional, high precision and bomb-spike), ${ }^{137} \mathrm{Cs},{ }^{210} \mathrm{~Pb}$, stable $\mathrm{Pb}$ isotopic ratios, trace metals, pollen and charcoal analyses. Palaeosea-level positions were determined by foraminiferal analyses. Relative sea level in Tasmania was within half a metre of present sea level for much of the last $6000 \mathrm{yr}$. Between 1900 and 1950 relative sea level rose at an average rate of $4.2 \pm 0.1 \mathrm{~mm} / \mathrm{yr}$. During the latter half of the 20th century the reconstructed rate of relative sea-level rise was $0.7 \pm 0.6 \mathrm{~mm} / \mathrm{yr}$. Our study is consistent with a similar pattern of relative sea-level change recently reconstructed for southern New Zealand. The change in the rate of sea-level rise in the SW Pacific during the early 20th century was larger than in the North Atlantic and could suggest that northern hemisphere landbased ice was the most significant melt source for global sea-level rise.
\end{abstract}

(c) 2011 Elsevier B.V. All rights reserved.

\section{Introduction}

Global sea-level rise during the 20th century has departed significantly from late Holocene trends of sea-level change (Bindoff et al., 2007). This is especially apparent in the North Atlantic Ocean, where instrumental observations show that 20th century sea-level rise was faster than average late Holocene trends reconstructed by geological methods (Gehrels et al., 2004; Shennan and Horton, 2002). North Atlantic proxy sea-level reconstructions show a distinct change in slope in the late 19th century or early 20th century, signalling an increase in the rate of relative sea-level rise (Donnelly et al., 2004; Gehrels et al., 2005; Kemp et al., 2009; Leorri et al., 2008). Tide gauges from Europe and North America have recorded evidence for an increase in the rate of sea-level rise in the 1920s (Woodworth et al., 2009). Positive deviations from linear sea-level trends represent important climate signals if they are persistent for several decades and found across wider geographical areas.

\footnotetext{
* Corresponding author.

E-mail address: wrgehrels@plymouth.ac.uk (W.R. Gehrels).
}

Gehrels et al. (2008) documented the first clear inflexion in a recent relative sea-level record from the Southern Hemisphere. They reconstructed changes in sea level during the past $500 \mathrm{yr}$ from salt-marsh sediments at Pounawea in southeastern New Zealand. A significant change in the rate of sea-level rise was recorded here in the early $1900 \mathrm{~s}$, when relative sea-level rise increased from $0.3 \pm 0.3 \mathrm{~mm} / \mathrm{yr}$ to $2.8 \pm 0.5 \mathrm{~mm} / \mathrm{yr}$. The rapid rate of relative sea-level rise for the 20th century was in agreement with tide-gauge data from southern New Zealand at Lyttelton and Bluff.

The substantial change in rate of sea-level rise recorded in New Zealand highlights the need for more proxy sea-level reconstructions from the SW Pacific region. The available tide-gauge records are not long enough to capture the acceleration. In Fig. 1 we plot seven long tide-gauge records from Australia and New Zealand. The longest records from Australia and New Zealand started in 1886 (Sydney, Fort Denison 1) and 1900 (Dunedin), respectively. Linear trends (uncorrected for crustal motion) are variable and, when calculated from 1930, range from $0.9 \mathrm{~mm} / \mathrm{yr}$ (Fremantle) to $2.6 \mathrm{~mm} / \mathrm{yr}$ (Newcastle). There is little evidence for any accelerations in these records over this time period (Watson, 2011).

In this study we present a new proxy relative sea-level record for Tasmania, based on analyses of salt-marsh sediments. Some of the 

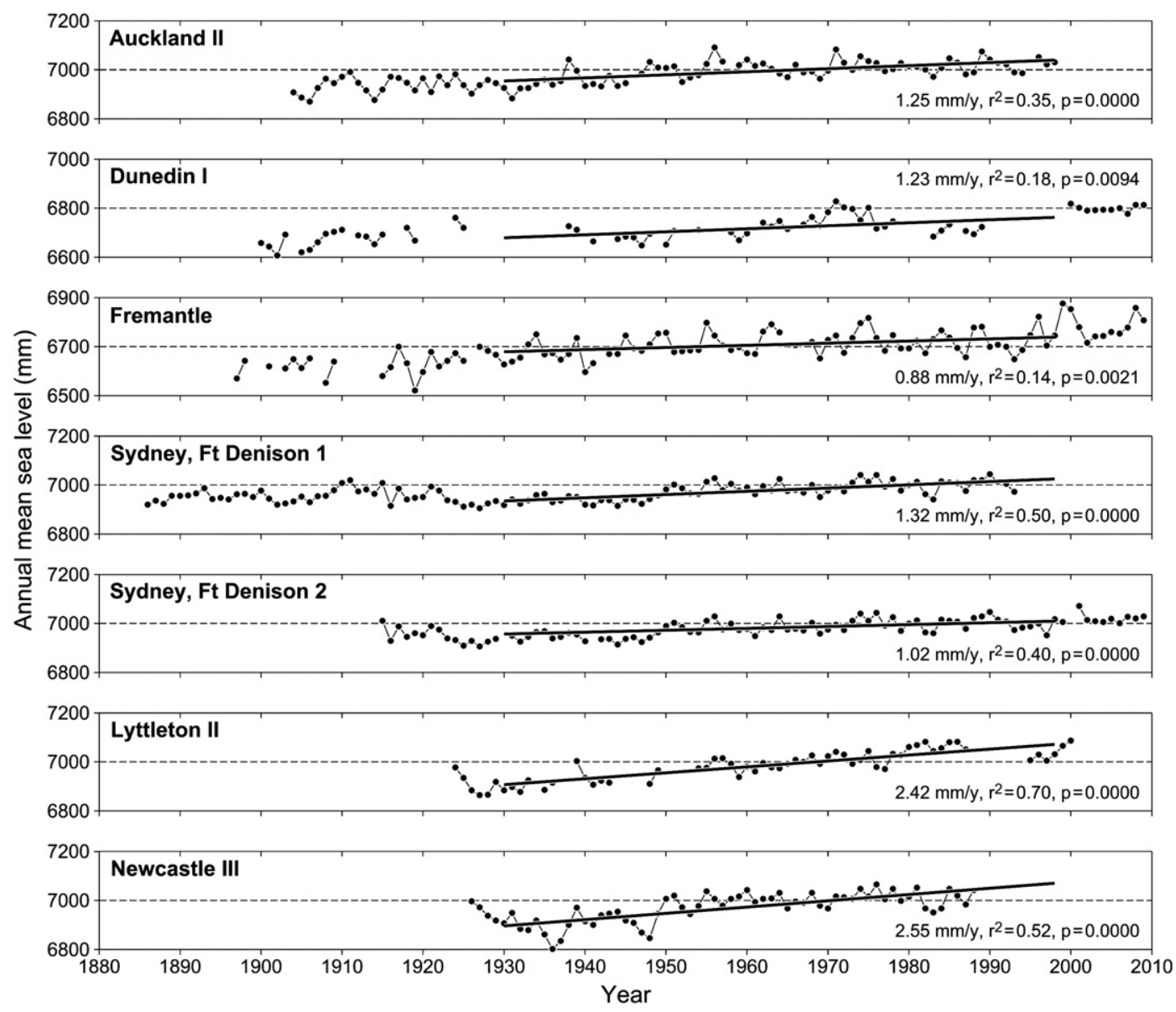

Fig. 1. Tide-gauge observations of relative sea level from Australia and New Zealand with linear trends from 1930 to 1998. Data from PSMSL (2011).

Southern Hemisphere's earliest sea-level observations were recorded in 1839-1842 at Port Arthur in southeastern Tasmania. These were used to calculate a rate of relative sea-level rise of $0.8 \pm 0.2 \mathrm{~mm} / \mathrm{yr}$ for the period 1841-2002 (Hunter et al., 2003; Pugh et al., 2002). Scattered additional sea-level measurements at Port Arthur from the late 1800s, and 1972 were in broad agreements with these findings. The limited data set, however, only allowed for the calculation of a linear trend which is slower than those recorded by Australian tide-gauges for the 20th century (Fig. 1). The data do not capture a change in slope in the record, similar to the one found in New Zealand. Available tide-gauge records in Tasmania are too short for comparisons with historical data; stations at Spring Bay (since 1992) and Burnie (since 1993) have recorded relative sea-level rise of $3.7 \mathrm{~mm} / \mathrm{yr}$ and $3.0 \mathrm{~mm} / \mathrm{yr}$, respectively (PSMSL, 2011). In this paper a proxy sea-level reconstruction from Tasmania is used to explore the early 20th century increase in the rate of relative sea-level rise in the region, to test the validity of the Port Arthur sea-level record, and to extend existing instrumental observations back in time.

\section{Study site and methods}

Salt marshes are vegetated tidal flats that accumulate vertically in response to rising sea levels. Their sediments record former sea levels as the surface of the marsh accretes vertically in response to the frequency and duration of tidal inundation. Micro-organisms, such as diatoms and foraminifera, occupy distinct vertical niches on the salt marsh and, when found in fossil sediments, allow precise reconstructions of former positions of sea level, with precisions as high as \pm $0.05 \mathrm{~m}$ in microtidal areas (Callard et al., 2011; Southall et al., 2006).
In Tasmania and New Zealand, Holocene sea level reached its present altitude around $6000 \mathrm{yr}$ ago and has remained relatively stable since (Gibb, 1986; Lambeck and Nakada, 1990). As a consequence, saltmarsh sediments are rarely thicker than $0.5 \mathrm{~m}$. Many salt marshes formed relatively recently as new accommodation space was created by relative sea-level rise (Gehrels et al., 2008). Measurements of (sub) decadal to centennial marsh accretion rates and analyses of the changing marsh sub-environments therefore provide a means to reconstruct recent changes in relative sea level from salt-marsh sediments.

Our study site is the Little Swanport Estuary on Tasmania's east coast (Fig. 2). This estuary contains some of the most pristine salt marshes in Tasmania. The outlet into the Tasman Sea is bedrock-framed and is permanently open (cf. Roy et al., 2001). The intertidal zone contains mudflat and salt-marsh habitats (Hedge and Kriwoken, 2000). The tidal range in the estuary is $0.7-1 \mathrm{~m}$. The Little Swanport River, an intermittent watercourse, enters the estuary in the northwestern part of Watch House Bay.

We used gouge cores to establish the stratigraphy of the salt marsh in the western part of the estuary. We analysed sediments for foraminiferal content to establish the height at which sediments were deposited within the intertidal frame. This was achieved by comparison with the vertical distribution of modern foraminifera in the marshes of the estuary as documented by Callard et al. (2011). Techniques for foraminiferal analyses followed Gehrels (2002) and Callard et al. (2011). All cores were surveyed relative to Australian Height Datum (AHD).

Ages of sea-level index points were determined by radiometric dating techniques (Accelerator Mass Spectrometry (AMS) ${ }^{14} \mathrm{C},{ }^{137} \mathrm{Cs}$, ${ }^{210} \mathrm{~Pb}$ ) and by chronostratigraphic markers (metal concentrations, $\mathrm{Pb}$ 

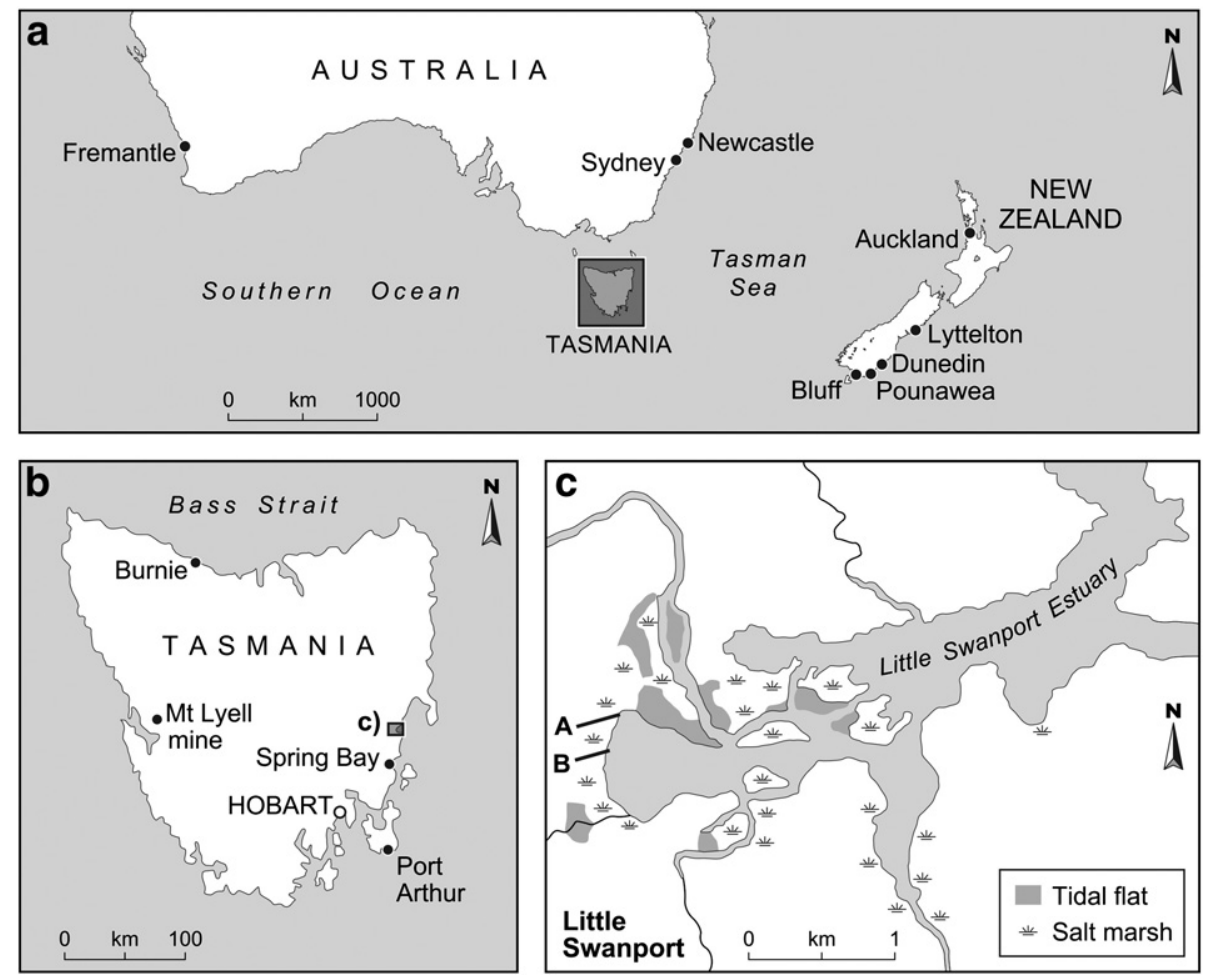

Fig. 2. Location of Tasmania (a), Little Swanport (b) and the coring transects (c). Locations of other places mentioned in the text are also shown.

isotopic ratios, and pollen). We used bomb-spike $\mathrm{AMS}^{14} \mathrm{C}$ for sediments younger than $\sim 60 \mathrm{yr}$ and high-precision $\mathrm{AMS}^{14} \mathrm{C}$ for sediments older than $60 \mathrm{yr}$ (Kemp et al., 2009; Marshall et al., 2007). The ${ }^{210} \mathrm{~Pb}$ method is suitable to date sediments younger than $\sim 120 \mathrm{yr}$. Measurements of ${ }^{137} \mathrm{Cs}$ were used to detect the 1965 level (when nuclear bomb testing was globally at its peak). Isotopic ratios of $\mathrm{Pb}$ and metal concentrations in the sediment $(\mathrm{Pb}, \mathrm{Cu}, \mathrm{Zn})$ provided ages for local and regional pollution events in the 19th and 20th centuries (Gehrels et al., 2006, 2008; Marshall et al., 2007). Pollen analyses provide a useful 19th century marker by revealing a distinct change in vegetation resulting from the first settlement by Europeans.

AMS ${ }^{14} \mathrm{C}$ analyses were conducted at the Scottish Universities Environmental Research Centre AMS Facility, East Kilbride, Scotland. We dated plant fragments that were clearly broken and detrital in nature and did not occur near the edge of the core. We also dated one algal mat and two shells. The plant fragments and the algal mat are associated with foraminifera and are considered to be precise palaeo-surface indicators. All ${ }^{14} \mathrm{C}$ samples were pre-treated using standard methods, converted to carbon dioxide by combustion in sealed quartz tubes (plant fragments and algal mat) or acid hydrolysis (shells), and graphitised by iron-zinc reduction. By convention, all ${ }^{14} \mathrm{C}$ results were normalised to $\delta^{13} \mathrm{C}\left({ }^{13} \mathrm{C} /{ }^{12} \mathrm{C}\right.$ ratio expressed in \% units relative to the Vienna PDB standard) of $-25 \%$ o to correct for isotopic fractionation (Stuiver and Polach, 1977). The $\delta^{13} \mathrm{C}$ values used for this correction were determined on an aliquot of sample $\mathrm{CO}_{2}$ by isotope ratio mass spectrometry at the NERC Radiocarbon Facility, or in the case of high precision samples (Marshall et al., 2007), using $\delta{ }^{13} \mathrm{C}$ values determined during AMS measurement. All ${ }^{14} \mathrm{C}$ results are expressed as \% modern and, where appropriate (i.e. $<100 \%$ modern), conventional radiocarbon ages BP (before present; where $0 \mathrm{BP}=\mathrm{AD} 1950$ ).

Contiguous $1 \mathrm{~cm}$ sediment slices of the cores were processed for radionuclide and geochemical analysis (see Supplementary Text S1). The activities of the radionuclides ${ }^{210} \mathrm{~Pb},{ }^{214} \mathrm{~Pb},{ }^{226} \mathrm{Ra},{ }^{137} \mathrm{Cs}$ and ${ }^{241} \mathrm{Am}$ were determined in the CORiF laboratory at Plymouth using an Ortec HPGe well-type coaxial low background intrinsic germanium detector.
Trace and major element analyses were carried out at the National Oceanography Centre (Southampton) on a Thermo Fisher Scientific X-Series II ICP-MS. Isotopic data were acquired at the National Oceanography Centre (Southampton) using a Thermo Fisher Scientific Neptune multi-collector ICP-MS.

Pollen was extracted from the sediments using the methodology of van der Kaars (1991) and identification was assisted by the Australasian Pollen and Spore Atlas (APSA Members, 2008) and Macphail and Hope (2003).

\section{Results}

\subsection{Litho- and biostratigraphy}

We established two coring transects (Fig. 3) across the salt marsh in Watch House Bay in the western part of the estuary $\left(42^{\circ} 20^{\prime} 31^{\prime \prime} \mathrm{S}\right.$ $\left.147^{\circ} 55^{\prime} 55^{\prime \prime} \mathrm{E}\right)$. The basement here consists of weathered dark-green Triassic volcaniclastic sandstones (Forsyth and Gulline, 1979). The lowest Holocene unit is a grey shell-rich clay which follows the topography of the substrate in Transect $A$ and reaches a maximum elevation of $0.2 \mathrm{~m}$ below AHD at the western end of this transect. Molluscs in this unit include oysters (Ostrea angasi), gastropods (Batillaria australis, Austrocochlea porcata) and bivalves (Spisula trigonella). The foraminifera are mainly Ammonia spp. with occurrences of Elphidium spp. and test linings of agglutinated foraminifera. These macro- and microfossils are all indicative of a shallow subtidal or low intertidal environment. The shell-rich unit is overlain in Transect A by a grey silty clay containing bivalves (Mactra pura) and gastropods (Bembicium auratum). In Transect B the shell-rich clay is thicker and occurs at the same level as the grey silty clay unit. Foraminifera in the silty clay unit include Ammobaculites foliaceus and Ammobaculites agglutinans, indicative of a tidal flat environment (Yassini and Jones, 1995). These foraminifera are also found higher up in the sequence where fine roots appear, interpreted as low salt marsh. The stratigraphy is capped by a darkbrown salt-marsh peat. This peat contains upper salt-marsh foraminifera throughout, which is an indication that the accretion rate of this 

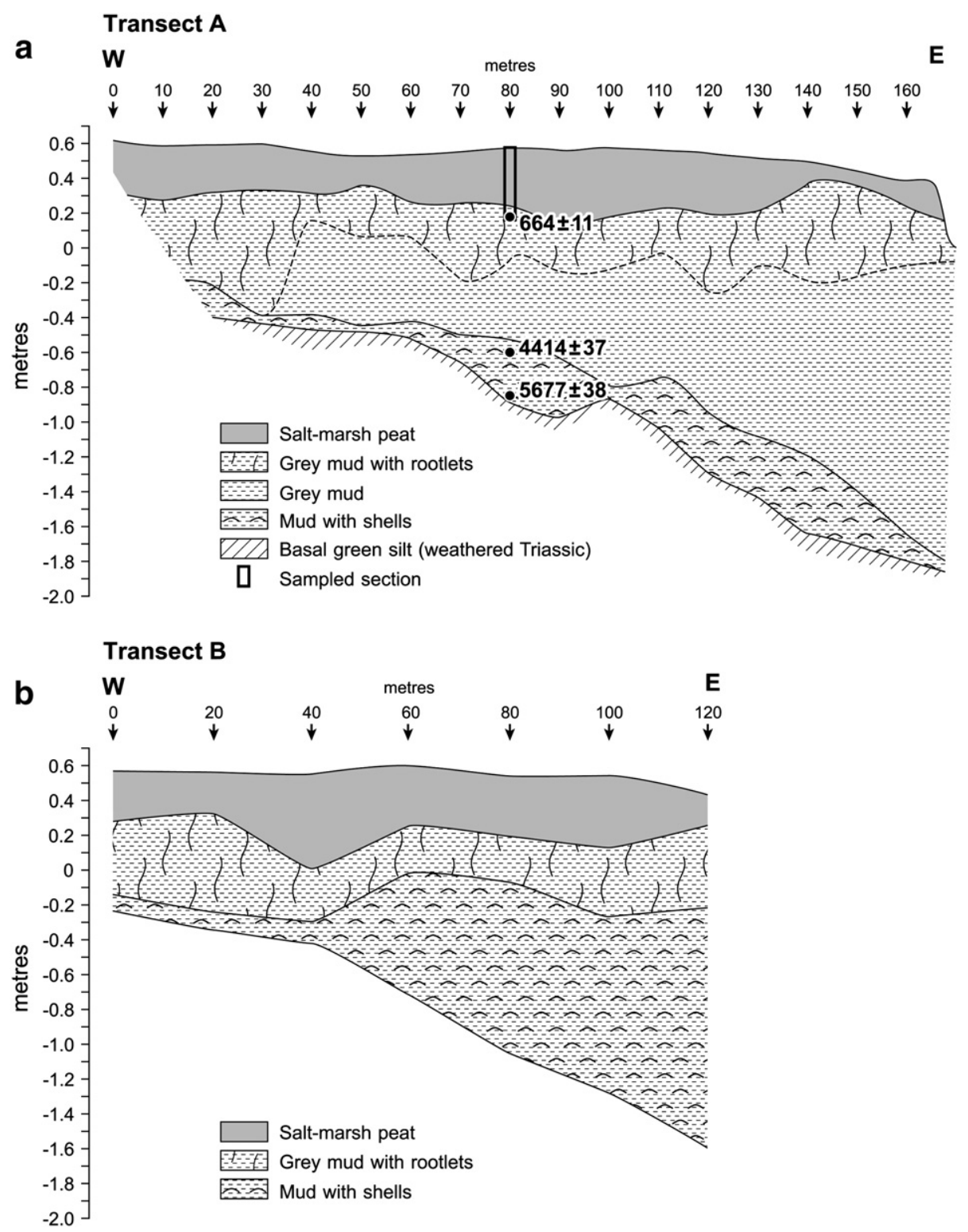

Fig. 3. Stratigraphy along (a) Transect A and (b) transect B. See Fig. 2 for location. Core 80 along transect A was selected for detailed analyses.

high salt-marsh peat was close to the rate of sea-level rise. We therefore subjected this unit to detailed foraminiferal and chronological analyses in core LSP-80.

The upper $42 \mathrm{~cm}$ of core LSP-80 contains the high salt-marsh foraminifera Trochammina inflata, Jadammina macrescens, Trochamminita salsa and Trochamminita irregularis (Supplementary Figure A1). The appearance of $T$. salsa at $37 \mathrm{~cm}$ is significant, because this is the highest foraminiferal species found in the salt marsh today (Callard et al., 2011), indicating that the highest tide level must have risen by about $0.3 \mathrm{~m}$ since the sediments at this level were deposited. Between 28 and $11 \mathrm{~cm}$, the assemblage is dominated by $T$. inflata, signifying slightly lower (by $\sim 10 \mathrm{~cm}$ ) marsh-surface conditions. The upper $10 \mathrm{~cm}$ of the core contains $T$. irregularis, also a species that lives in the upper high marsh.

The sediments contain more sand and silt towards the top of the sequence and there is a silty layer at $0.09-0.18 \mathrm{~m}$ with low concentrations of foraminifera. Apart from this layer, the bulk density increases slowly but steadily downcore, indicating some compaction (Supplementary Figure A2). Correlation between bulk density and total organic carbon $\left(r^{2}=0.64\right)$ shows that this compaction has occurred primarily as a consequence of organic matter decay. We calculated the amount of compaction by assuming that the salt-marsh sediments had the same bulk density as the top sample of the core $\left(0.25 \mathrm{~g} / \mathrm{cm}^{2}\right)$ when they were deposited and that between $0.30 \mathrm{~m}$ and $0.33 \mathrm{~m}$ depth the sediments were fully compacted. We then calculated for each centimetre slice between 0.01 and $0.30 \mathrm{~m}$ in the core its original thickness by 'stretching' the slice to its assumed original bulk density. We only did this for sediments that displayed a consistent lithology; no compaction was assumed to have occurred in the silty section between $0.09 \mathrm{~m}$ and $0.18 \mathrm{~m}$ core depth. The accumulated vertical displacement thus calculated reached a maximum of about $0.06 \mathrm{~m}$ at $0.30 \mathrm{~m}$ core depth. We cannot account for any compaction in the deeper minerogenic sediments below the salt-marsh facies, but we assume that most compaction in these sediments would have occurred before the recent salt-marsh sediments were deposited, which, given their age (4000$5000 \mathrm{yr}$ ) is plausible.

\subsection{Chronostratigraphy}

Our AMS ${ }^{14} \mathrm{C}$ ages include six high-precision $\mathrm{AMS}{ }^{14} \mathrm{C}$ and ten conventional AMS ${ }^{14} \mathrm{C}$ analyses (Table 1 ). The high-precision ages were obtained by extending the counting time on the mass spectrometer until the 
Table 1

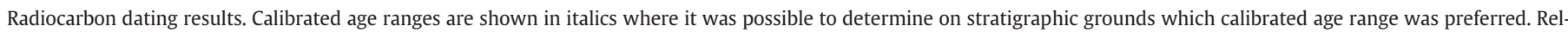
ative probabilities of calibrated age ranges (in \%) are shown in brackets. High-precision ages are those that have ${ }^{14} \mathrm{C}$ errors of $15 \mathrm{yr}$ or less at $1 \sigma$.

\begin{tabular}{|c|c|c|c|c|c|c|c|}
\hline $\begin{array}{l}\text { Lab. code } \\
\text { (SUERC-) }\end{array}$ & $\begin{array}{l}\text { Depth in } \\
\text { core }(\mathrm{cm})\end{array}$ & $\begin{array}{l}\text { Dry } \\
\text { weight }(\mathrm{g})\end{array}$ & Material & $\begin{array}{l}{ }^{14} \mathrm{C} \text { enrichment } \\
(\% \text { modern } \pm 1 \sigma)\end{array}$ & $\begin{array}{l}\delta^{13} C_{\mathrm{VPDB}} \pm \\
0.1 \%\end{array}$ & $\begin{array}{l}{ }^{14} \mathrm{C} \text { yr } \\
\mathrm{BP} \pm 1 \sigma\end{array}$ & Calibrated age ranges $(\mathrm{BC} / \mathrm{AD}, 2 \sigma)$ \\
\hline 28829 & 1.5 & 0.0115 & Grass & $110.90 \pm 0.51$ & -27.6 & $\mathrm{n} / \mathrm{a}$ & AD 1958.5-1959.2 (46), 1995.5-1996.8 (54), \\
\hline 28830 & 2.5 & 0.0146 & Plant stem & $128.99 \pm 0.59$ & -28.1 & $\mathrm{n} / \mathrm{a}$ & AD 1962.9-1963.3 (9), 1979.3-1981.1 (91) \\
\hline 28831 & 5.5 & 0.0078 & Grass & $126.36 \pm 0.55$ & -27.0 & $\mathrm{n} / \mathrm{a}$ & AD 1962.6-1963.1 (15), 1980.7-1982.6 (85) \\
\hline 28832 & 6.5 & 0.0064 & Grass & $124.41 \pm 0.57$ & -27.3 & $\mathrm{n} / \mathrm{a}$ & AD $1962.3-1963.0(20), 1982.0-1984.0(80)$ \\
\hline 28835 & 7.5 & 0.0069 & Grass & $110.17 \pm 0.51$ & -28.2 & $\mathrm{n} / \mathrm{a}$ & AD 1958.3-1959.1 (97), 1996.6-1996.8 (3) \\
\hline 28836 & 8.5 & 0.0044 & Grass & $98.36 \pm 0.43$ & -28.0 & $133 \pm 35$ & AD 1682-1730 (21), 1802-1953 (79) \\
\hline 28837 & 11.5 & 0.0073 & Grass stem & $98.66 \pm 0.45$ & -26.2 & $108 \pm 37$ & AD 1691-1727 (16), 1805-1954 (84) \\
\hline 28838 & 14.5 & 0.0102 & Plant stem & $98.73 \pm 0.45$ & -27.0 & $102 \pm 37$ & AD 1694-1726 (15), 1806-1954 (85) \\
\hline 29103 & 19.5 & 0.0031 & Grass leaf & $98.34 \pm 0.18$ & -26.6 & $135 \pm 14$ & AD $1698-1724(17), 1808-1869(38), 1876-1952$ (46) \\
\hline 29,102 & 27.5 & 0.0107 & Plant stem & $98.77 \pm 0.18$ & -13.9 & $99 \pm 14$ & $\begin{array}{l}\text { AD } 1712-1718(2), 1813-1836(33), 1884-1887(1), \\
1890-1923(56), 1950-1954(8)\end{array}$ \\
\hline 29108 & 30.5 & 0.0061 & Grass leaf & $97.43 \pm 0.18$ & -13.2 & $209 \pm 15$ & AD 1666-1688 (19), 1728-1804 (81) \\
\hline 29109 & 32.0 & 0.0087 & Grass leaf & $99.15 \pm 0.18$ & -15.7 & $68 \pm 15$ & $\begin{array}{l}\text { AD 1818-1826 (6), 1895-1898 (1), 1901-1906 } \\
\text { (3), 1951-1955 (91) }\end{array}$ \\
\hline 29114 & 41.5 & 0.0967 & Filamentous algae & $92.22 \pm 0.17$ & -16.9 & $651 \pm 15^{\mathrm{a}, \mathrm{b}}$ & AD $1403-1623(100)$ \\
\hline 29115 & 41.5 & 0.0967 & Filamentous algae & $91.92 \pm 0.17$ & -17.6 & $677 \pm 15^{\mathrm{a}, \mathrm{b}}$ & AD 1335-1346 (1), 1386-1619 (99) \\
\hline $\begin{array}{r}29114 / \\
29115\end{array}$ & 41.5 & 0.0967 & Filamentous algae & $\mathrm{n} / \mathrm{a}$ & $\mathrm{n} / \mathrm{a}$ & $664 \pm 11^{\mathrm{a}, \mathrm{c}}$ & AD 1395-1620 (100) \\
\hline 28447 & 119.0 & 0.865 & $\begin{array}{l}\text { Mactra pura (single valve, } \\
\text { found in horizontal position) }\end{array}$ & $57.72 \pm 0.27$ & 1.0 & $4414 \pm 37^{\mathrm{b}}$ & $2286-2940$ BC \\
\hline 28448 & 143.0 & 0.868 & $\begin{array}{l}\text { Spisula trigonella (bivalve, } \\
\text { found in vertical position) }\end{array}$ & $49.33 \pm 0.23$ & 1.0 & $5677 \pm 38^{\mathrm{b}}$ & $3880-4431$ BC (100) \\
\hline
\end{tabular}

\footnotetext{
a Assumed to contain 50\% marine carbon.

b Reservoir age is $455 \pm 120{ }^{14} \mathrm{C}$ yr BP (Gill, 1983).

c Average of SUERC-29114 and SUERC-29115
}

desired precision had been achieved (i.e. $2 \sigma$ age errors of $\pm 14-15{ }^{14} \mathrm{C} \mathrm{yr}$ ). In one case (algal mat at $0.415 \mathrm{~m}$ ), the sample was measured twice which reduced the age uncertainty to $11{ }^{14} \mathrm{C}$ yr (at $2 \sigma$ ). Of the ten conventional ages, five were 'bomb-spike' measurements (i.e. $>100 \%$ modern). These were calibrated using the Southern Hemisphere calibration curve (Hua and Barnetti, 2004) using Calibomb (Reimer et al., 2004). For all 'bomb-spike' results there were two possible calibration solutions due to the rising and falling parts of the bomb- ${ }^{14} \mathrm{C}$ curve; we used additional chronostratigraphic evidence to decide which was the most likely calibration solution (Table 1 ). We calibrated the other radiocarbon ages with the SHCal94 calibration curve for southern hemisphere terrestrial samples (McCormac et al., 2004), except for the shells for which we used the Marine09 calibration curve (Hughen et al., 2004), with a reservoir age of $455 \pm 120{ }^{14} \mathrm{C}$ yr $\mathrm{BP}(\Delta \mathrm{R}=-14 \pm 120 \mathrm{yr})$ as determined by Gill (1983) in Bass Strait, southern Australia (http:// radiocarbon.pa.qub.ac.uk/marine/). Some routine-precision ${ }^{14} \mathrm{C}$ dates (SUERC-28836, 28837, 28838) produced wide-ranging calibrated age ranges but were included in the age-depth modelling.

The carbon of the algal samples was assumed to stem from terrestrial as well as oceanic sources, by producing a composite calibration curve consisting of 50\% Marine09 (Reimer et al. 2009) and 50\% SHCal04. The regional marine reservoir age offset of $-14 \pm 120 \mathrm{yr}$ was assumed for the algal samples.

Analyses of ${ }^{137} \mathrm{Cs}$ reveal the 1965 Southern Hemisphere maximum of nuclear bomb testing at $5.5 \mathrm{~cm}$. Age determinations from ${ }^{210} \mathrm{~Pb}$ are complicated by low concentrations of unsupported ${ }^{210} \mathrm{~Pb}$ in the sediments, because of the dilution effect of the reworked silt. If samples from the minerogenic horizon are treated as an 'instantaneous' deposit (following Arnaud et al., 2006), the Constant Rate of Supply (CRS) model yields a chronology since 1920 .

Metal analyses reveal several markers (Supplementary Figure A2) which can be tied to the regional pollution history. The Little Swanport catchment has been spared from mining activities, but several open-cut mines in western Tasmania (mainly the Mt Lyell mine) transported metal-laden dust across the island, most notably since the mid 1930s (Harle et al., 2002; Mudd, 2009; Seen et al., 2004).

The ${ }^{206} \mathrm{~Pb} /{ }^{207} \mathrm{~Pb}$ profile of the core is remarkably similar to the marsh sediments of southern New Zealand (Gehrels et al., 2008) and shows characteristics of the $\mathrm{Pb}$ record from the Law Dome ice core in Antarctica (Van de Velde et al., 2005). Pb deposition is therefore likely to be atmospherically controlled. Several isotopic markers are apparent, e.g. the Southern Hemisphere increase in atmospheric $\mathrm{Pb}$ pollution in the $1890 \mathrm{~s}$ at $0.285 \mathrm{~m}$ (Vallelonga et al., 2002), the late 1940s minimum at $0.105 \mathrm{~m}$ (Wolff and Suttie, 1994) and the introduction of unleaded petrol in the late $1980 \mathrm{~s}$ at $0.025 \mathrm{~m}$. The widespread smelting of $\mathrm{Zn}$ since the 1930s (Mudd, 2009) required burning of coal, which also produced a distinct signal in the lead isotopes in the form of a reversal to higher ${ }^{206} \mathrm{~Pb} /{ }^{207} \mathrm{~Pb}$ ratios at $0.185 \mathrm{~m}$.

The pollen record shows exotic taxa appearing at $0.405 \mathrm{~m}$, signalling land clearance in Little Swanport which started in the 1830s with the development of salt workings (Rogers, 1991). The disturbance is also highlighted by a peak in micro-charcoal concentrations (Supplementary Figure A2). Widespread catchment disturbance and deforestation since the 1880 s is signalled by the first metal enrichment, the increase in grass pollen and the decrease in tree pollen from $0.355 \mathrm{~m}$.

In total, we obtained 31 ages from 23 levels in the core (Table 2). Almost all ages were in chronostratigraphical order, but some levels were dated by different methods which produced varying results. Also, the dating methods invariably produced a range of precisions. All ${ }^{14} \mathrm{C},{ }^{210} \mathrm{~Pb}$ and other age estimates were therefore combined to construct an age-depth model using Bayesian age-modelling software Bacon (Blaauw and Christen, 2011) to produce the best age estimates and associated age uncertainties for each level in the core. The software divided the core in 1-cm increments and modelled the accumulation rate for each increment. Accumulation rates were assumed a priori to vary between ca. 2 and $30 \mathrm{yr} / \mathrm{cm}$ (Supplementary Figure A3), whilst accumulation rates could vary much between neighbouring increments (a low prior distribution for the "memory"; Blaauw and Christen, 2011). For each dated level we calculated the best age estimate from the agedepth model and used this for our sea-level reconstruction.

\subsection{Relative sea-level estimation}

Table 2 lists the ages and depths of all palaeosea-level estimates established from analyses of core LSP80. At all dated levels, except $0.115 \mathrm{~m}$, we found foraminifera and for each we derive a former 
Table 2

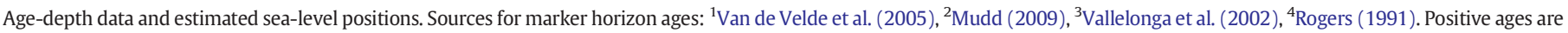

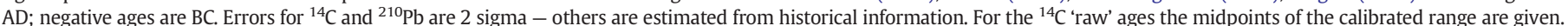

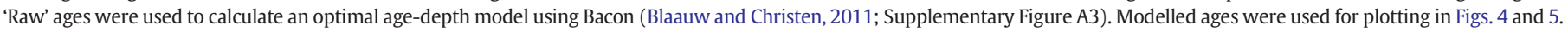

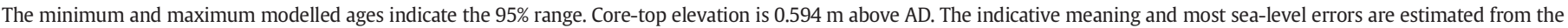
modern range of foraminifera (Callard et al., 2011). Sea-level errors for two oldest index points are estimated from tidal flat survey.

\begin{tabular}{|c|c|c|c|c|c|c|c|c|c|c|}
\hline $\begin{array}{l}\text { Depth } \\
\text { (m) }\end{array}$ & Dating method/marker & $\begin{array}{l}\text { 'Raw' } \\
\text { age }\end{array}$ & $\begin{array}{l}\text { Error } \\
(\mathrm{yr})\end{array}$ & $\begin{array}{l}\text { Modelled } \\
\text { age }\end{array}$ & $\begin{array}{l}\text { Minimum } \\
\text { age }\end{array}$ & $\begin{array}{l}\text { Maximum } \\
\text { age }\end{array}$ & $\begin{array}{l}\text { Indicative meaning } \\
(\mathrm{m})\end{array}$ & $\begin{array}{l}\text { Compaction } \\
(\mathrm{m})\end{array}$ & $\begin{array}{l}\text { Sea level } \\
(\mathrm{m})\end{array}$ & $\begin{array}{l}\text { Error } \\
(\mathrm{m})\end{array}$ \\
\hline 0.005 & ${ }^{210} \mathrm{~Pb}$ & 2000 & 2 & 2000 & 2011 & 1996 & 0.56 & 0.005 & 0.03 & 0.10 \\
\hline 0.015 & ${ }^{14} \mathrm{C}$ bomb & 1996 & 1 & 1994 & 2001 & 1990 & 0.56 & 0.009 & 0.03 & 0.10 \\
\hline 0.015 & ${ }^{210} \mathrm{~Pb}$ & 1994 & 3 & 1994 & 2001 & 1990 & 0.56 & 0.009 & 0.03 & 0.10 \\
\hline 0.025 & ${ }^{14} \mathrm{C}$ bomb & 1980 & 1 & 1990 & 1994 & 1978 & 0.58 & 0.014 & 0.01 & 0.10 \\
\hline 0.025 & ${ }^{210} \mathrm{~Pb}$ & 1990 & 4 & 1990 & 1994 & 1978 & 0.58 & 0.014 & 0.01 & 0.10 \\
\hline 0.025 & Unleaded petrol introduction & 1988 & 2 & 1990 & 1994 & 1978 & 0.58 & 0.014 & 0.01 & 0.10 \\
\hline 0.035 & ${ }^{210} \mathrm{~Pb}$ & 1985 & 4 & 1980 & 1987 & 1968 & 0.57 & 0.020 & 0.01 & 0.10 \\
\hline 0.045 & ${ }^{210} \mathrm{~Pb}$ & 1978 & 6 & 1968 & 1975 & 1963 & 0.61 & 0.024 & -0.04 & 0.10 \\
\hline 0.055 & ${ }^{14} \mathrm{C}$ bomb & 1963 & 0 & 1963 & 1965 & 1961 & 0.58 & 0.028 & -0.01 & 0.10 \\
\hline 0.055 & ${ }^{210} \mathrm{~Pb}$ & 1969 & 7 & 1963 & 1965 & 1961 & 0.58 & 0.028 & -0.01 & 0.10 \\
\hline 0.055 & ${ }^{137} \mathrm{Cs}$ & 1965 & 1 & 1963 & 1965 & 1961 & 0.58 & 0.028 & -0.01 & 0.10 \\
\hline 0.065 & ${ }^{210} \mathrm{~Pb}$ & 1959 & 9 & 1962 & 1963 & 1959 & 0.59 & 0.030 & -0.03 & 0.10 \\
\hline 0.065 & ${ }^{14} \mathrm{C}$ bomb & 1963 & 0 & 1962 & 1963 & 1959 & 0.59 & 0.030 & -0.03 & 0.10 \\
\hline 0.075 & ${ }^{14} \mathrm{C}$ bomb & 1959 & 0 & 1959 & 1960 & 1957 & 0.55 & 0.034 & 0.00 & 0.10 \\
\hline 0.075 & ${ }^{210} \mathrm{~Pb}$ & 1948 & 11 & 1959 & 1960 & 1957 & 0.55 & 0.034 & 0.00 & 0.10 \\
\hline 0.085 & ${ }^{14} \mathrm{C}$ & 1878 & 76 & 1955 & 1956 & 1951 & 0.51 & 0.039 & 0.04 & 0.10 \\
\hline 0.105 & Start of post WW2 ${ }^{206} \mathrm{~Pb} /{ }^{207} \mathrm{~Pb}$ decline ${ }^{1}$ & 1948 & 2 & 1948 & 1952 & 1944 & 0.50 & 0.039 & 0.03 & 0.10 \\
\hline 0.115 & ${ }^{14} \mathrm{C}$ & 1880 & 74 & 1945 & 1950 & 1940 & $\mathrm{n} / \mathrm{a}$ & 0.039 & $\mathrm{n} / \mathrm{a}$ & $\mathrm{n} / \mathrm{a}$ \\
\hline 0.135 & ${ }^{210} \mathrm{~Pb}$ & 1936 & 12 & 1940 & 1946 & 1932 & 0.50 & 0.039 & 0.00 & 0.10 \\
\hline 0.145 & ${ }^{210} \mathrm{~Pb}$ & 1922 & 15 & 1938 & 1943 & 1928 & 0.50 & 0.039 & -0.01 & 0.10 \\
\hline 0.145 & ${ }^{14} \mathrm{C}$ & 1880 & 74 & 1938 & 1943 & 1928 & 0.50 & 0.039 & -0.01 & 0.10 \\
\hline 0.185 & Start of large-scale $\mathrm{Zn}$ mining, use of coal for smelting ${ }^{2}$ & 1937 & 5 & 1926 & 1934 & 1916 & 0.50 & 0.039 & -0.05 & 0.10 \\
\hline 0.195 & ${ }^{14} \mathrm{C}$ & 1914 & 38 & 1922 & 1931 & 1913 & 0.51 & 0.039 & -0.07 & 0.10 \\
\hline 0.275 & ${ }^{14} \mathrm{C}$ & 1907 & 17 & 1896 & 1904 & 1883 & 0.57 & 0.057 & -0.19 & 0.10 \\
\hline 0.285 & Start of ${ }^{206} \mathrm{~Pb} /{ }^{207} \mathrm{~Pb}$ decline ${ }^{1}$ & 1895 & 5 & 1892 & 1900 & 1874 & 0.61 & 0.060 & -0.24 & 0.10 \\
\hline 0.320 & ${ }^{14} \mathrm{C}$ & 1904 & 2.5 & 1887 & 1861 & 1881 & 0.65 & 0.060 & -0.31 & 0.10 \\
\hline 0.355 & $\begin{array}{l}\text { Start of catchment disturbance, } \mathrm{Pb} \text { enrichment, start of } \\
\text { land clearance } \mathrm{e}^{1,3,4}\end{array}$ & 1880 & 10 & 1863 & 1874 & 1842 & 0.60 & 0.060 & -0.31 & 0.10 \\
\hline 0.405 & First appearance of exotic pollen, charcoal peak ${ }^{4}$ & 1830 & 5 & 1828 & 1842 & 1812 & 0.52 & 0.060 & -0.27 & 0.10 \\
\hline 0.415 & ${ }^{14} \mathrm{C}$ & 1508 & 113 & 1824 & 1791 & 1850 & 0.53 & 0.060 & -0.29 & 0.10 \\
\hline 1.190 & ${ }^{14} \mathrm{C}$ & -2613 & 327 & $\mathrm{n} / \mathrm{a}$ & $\mathrm{n} / \mathrm{a}$ & $\mathrm{n} / \mathrm{a}$ & -0.20 & $\mathrm{n} / \mathrm{a}$ & -0.40 & 0.40 \\
\hline 1.430 & ${ }^{14} \mathrm{C}$ & -4156 & 276 & $\mathrm{n} / \mathrm{a}$ & $\mathrm{n} / \mathrm{a}$ & $\mathrm{n} / \mathrm{a}$ & -0.50 & $\mathrm{n} / \mathrm{a}$ & -0.34 & 0.50 \\
\hline
\end{tabular}

sea-level height (i.e. a sea-level index point) following Gehrels (1999) and based on its age and the relationship:

$\mathrm{S}=\mathrm{H}-\mathrm{I}+\mathrm{C}$

where $\mathrm{S}$ is former sea level, $\mathrm{H}$ is sample height relative to $\mathrm{AD}$, I is the indicative meaning (or palaeomarsh-surface elevation) relative to AHD calculated by a transfer function from the modern distributions of salt-marsh foraminifera (Callard et al., 2011) and C is compaction. The index points based on shell dates were associated with tidal flat foraminifera which are not represented in our modern foraminiferal dataset. For these we estimated an indicative meaning based on the surveyed height of the tidal flat beyond our marsh transects and we assigned a larger vertical error to these samples to reflect the uncertainty associated with the estimates.

Where counts of foraminifera were too low $(<50)$ to calculate an indicative meaning using the transfer function we interpolated between samples (Supplementary Figure A1). Foraminifera were sampled at $1 \mathrm{~cm}$ resolution, but at some levels we obtained a date at the contact between two foraminiferal samples. In such instances we averaged the indicative meaning for the samples immediately above and below the dated level.

\section{Discussion}

The Little Swanport estuary can be classified as an open, tidedominated (micro-tidal) drowned river valley, which has reached an intermediate stage of infill since the stabilisation of sea-level rise at about 6000 cal.yr BP (Roy et al., 2001). The stratigraphy of Little
Swanport marsh contains the distinct signature of the late Holocene and recent relative sea-level history of the eastern Tasmanian coast. Tidal deposits of middle Holocene age are found at the base of the sequence. The indicative meaning of these deposits is low intertidal or shallow sub-tidal, as indicated by the macro- and microfauna. Towards the top of the minerogenic deposits, fine roots start appearing, indicating that the tidal flat deposits have built up sufficiently to allow the colonisation by low salt-marsh plants. An important change in the microfauna occurs around $0.38 \mathrm{~m}$ depth. Below this depth, we find the low intertidal foraminifera A. foliaceus and A. agglutinans (their concentrations are too low to be shown in Supplementary Figure A1). However, the foraminiferal assemblage that appears at $0.38-0.42 \mathrm{~m}$ (T. inflata, J. macrescens, T. salsa and T. irregularis) is indicative of the highest marsh environment and represents the leading edge of the most recent transgression that affected the embayment. This implies that the low intertidal deposits would have fallen temporarily dry before they were re-flooded and re-colonised by salt marsh. Our chronology shows that the period of non-deposition lasted perhaps as long as $400 \mathrm{yr}$, from the 1400 s until the early 1800 s, as marked by a radiocarbon date at $0.42 \mathrm{~m}$ and the appearance of the first exotic pollen at $0.41 \mathrm{~cm}$ in the core, but the age of the algal mat at $0.42 \mathrm{~m}$ is imprecise due to uncertainty about the marine reservoir correction. However, this type of facies change is in sharp contrast with a conformable progressive infilling sequence, which would result in a continuous succession from tidal flat, to low marsh, to high marsh. The same sequence (i.e. tidal flat deposits directly overlain by high marsh facies) is found in the salt marshes of southern New Zealand (Gehrels et al., 2008) and we have also found this type of stratigraphy in all other salt marshes in southeastern Tasmania where we cored. 


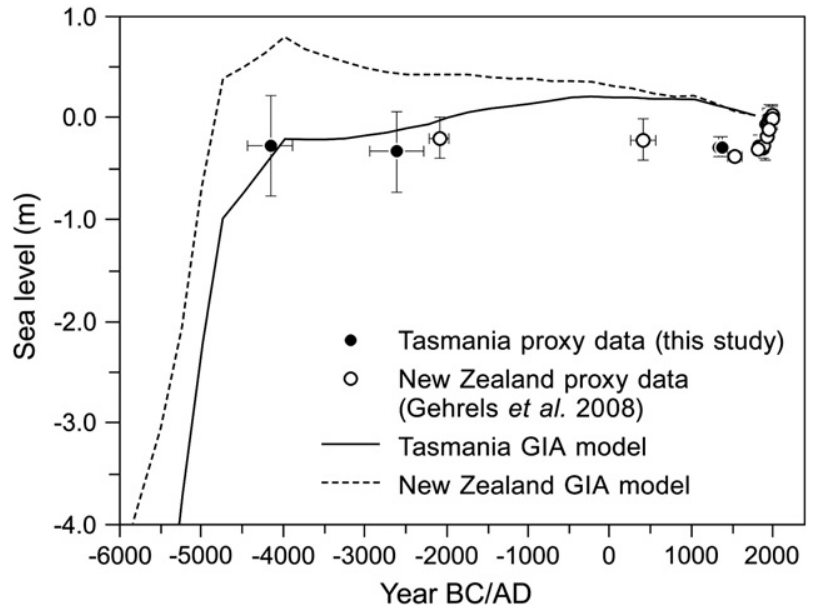

Fig. 4. Middle and late Holocene proxy sea-level data from Tasmania (this study) and southern New Zealand (Gehrels et al., 2008) and GIA model data (Lambeck pers. comm.).

Our sea-level reconstruction spans the last $200 \mathrm{yr}$, but also includes three older index points (Fig. 5a). Dates on shells place sea level slightly below its present level during the middle Holocene. This is in general agreement with models of glacial isostatic adjustment (GIA) which predict middle Holocene highstands for New Zealand and mainland Australia, but not for Tasmania (Lambeck and Nakada, 1990). The GIA model predictions for Little Swanport in eastern Tasmania and Pounawea in southern New Zealand (Lambeck pers. comm.) are based on model ma2A with Earth parameters of $65 \mathrm{~km}$ for lithospheric thickness, $2 \times 10^{20}$ Ps for upper mantle viscosity and $10^{22}$ Ps for lower mantle viscosity. The model overpredicts the observed sea-level positions in New Zealand, but matches the observations for Tasmania quite closely, especially when it is considered that the 1000 year model time steps cannot capture the rapid rise at the beginning of the 20th century (Fig. 4). Last interglacial shorelines in southeastern Tasmania in the Hobart area are found at ca. $24 \mathrm{~m}$ above present sea level, indicating a mean neotectonic background uplift rate of about $0.2 \mathrm{~mm} / \mathrm{yr}$ over millennial timescales (Murray-Wallace and Goede, 1991).

Our youngest shell date suggests that sea level during the 15th century was ca. $0.3 \mathrm{~m}$ below present. Our earliest historical proxy sea-level estimate is from 1830 when sea level was $0.27 \pm 0.10 \mathrm{~m}$ below its present level (Fig. 5a). This is lower than estimated from the historical measurements at Port Arthur (Fig. 5b) where sea level was estimated at $-0.14 \pm 0.02 \mathrm{~m}$ in 1841-1842 (Hunter et al., 2003). This could simply represent statistical variability (there is a small probability that this disagreement could happen by chance), or it could suggest that one or more of the uncertainties have been poorly estimated. Neotectonic differential land motion would be small over $170 \mathrm{yr}$ and the regional trend suggests greater uplift towards northern Tasmania (Bryant, 1992). A major uncertainty in sea level at Port Arthur in 1841-1842 relates to the levelling between the mark and the tide gauge when the mark was struck in 1841. This procedure relied on an assumption that the sea surface between these points was level at that time, an assumption which would be invalidated if significant seiching motion occurred (Hunter et al., 2003). Alternatively, it is possible that we underestimated compaction in our reconstruction. However, our reconstruction for the latter part of the 19th century is in good agreement with the late 19th century historical observations of $-0.23 \pm 0.10 \mathrm{~m}$ (mean for 1875-1905; Hunter et al., 2003; Pugh et al., 2002) and $-0.19 \pm 0.12$ for one month of observations in February 1889 (Mault, 1890). Hunter et al. (2003) also report a sea-level estimate of $0.01 \pm 0.13 \mathrm{~m}$ for 1888 , but this is based on a single observation.
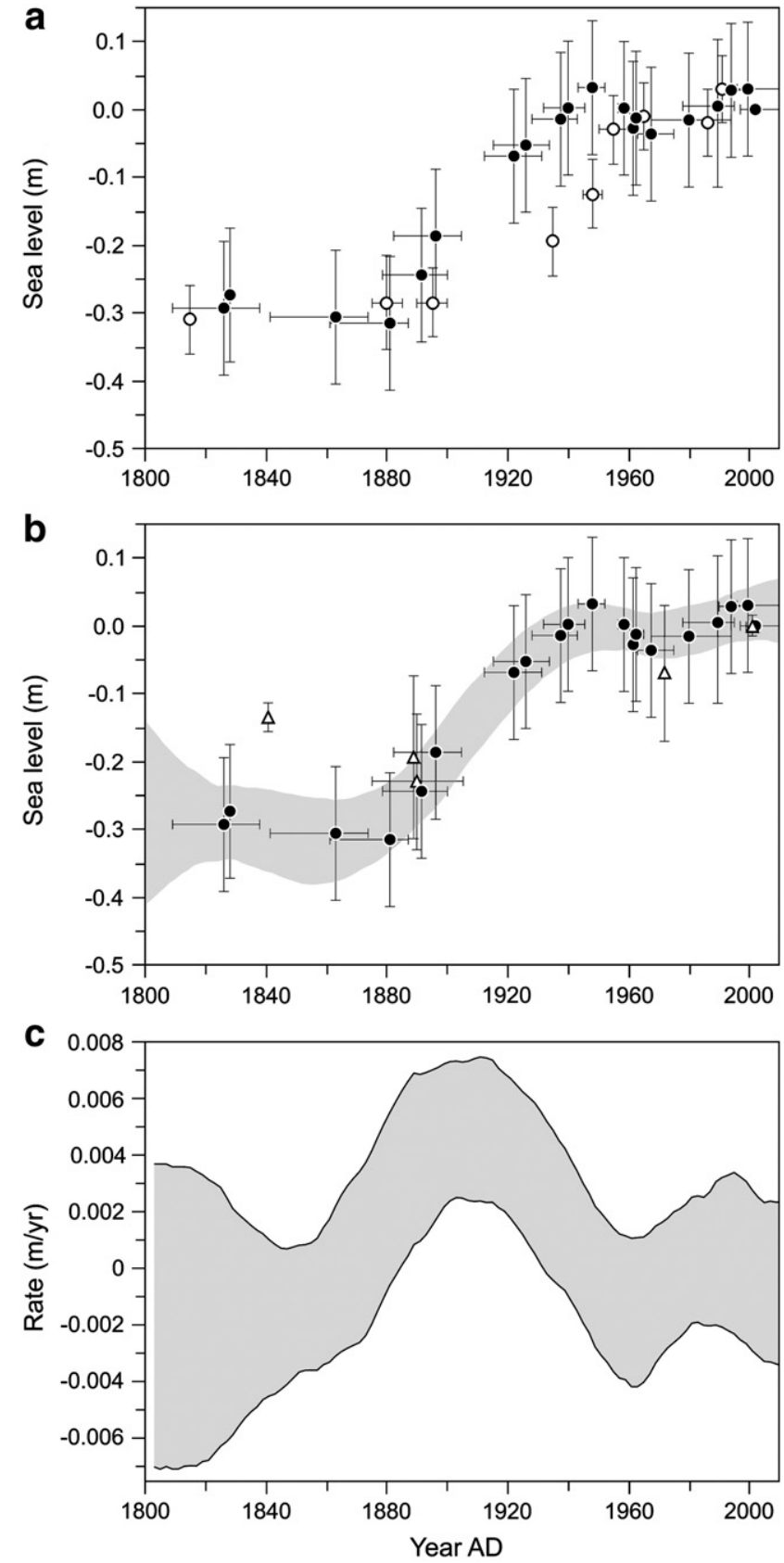
- Tasmania proxy data (this study)
- New Zealand proxy data (Gehrels et al. 2008)
$\Delta$ Tasmania historical data (Hunter et al. 2003; Mault 1889)

Fig. 5. a) Proxy sea-level data from Tasmania (this study) for the last $200 \mathrm{yr}$ compared with recent proxy data from southern New Zealand (Gehrels et al., 2008). b). Proxy sea-level data from Tasmania (this study) compared with historical data from Hunter et al. (2003) and Mault (1890). The envelope represents the 68\% confidence limits, taking into account proxy and chronological uncertainties. c). Rate estimates for the Tasmania sea-level reconstruction based on calculating the slope every second year between 1800 and 2010 for all iterations of the age-depth model (Supplementary Figure A3). The envelope represents the $68 \%$ confidence limits.

The earliest sign of a departure from the pre-20th century flat sealevel trend occurred around 1880 and by 1900 sea level had risen above the levels of the preceding century (Fig. 5b). The rate of 20th century sea-level rise reconstructed from our data is $1.5 \pm 0.4 \mathrm{~mm} / \mathrm{yr}$. Most of the rise occurred before the 1950s. In fact, between 1900 and 
1950 we calculate from our reconstruction a rate of $4.2 \pm 0.1 \mathrm{~mm} / \mathrm{yr}$. From 1950 to 2000, the mean rate was $0.7 \pm 0.6 \mathrm{~mm} / \mathrm{yr}$. In Fig. 5c we plot the rate changes with $68 \%$ confidence limits. This graph shows that highest rates of sea-level rise occurred in the 1910s (0.3$0.8 \mathrm{~mm} / \mathrm{yr}$ ), with a second peak in the 1990s. The early 20th century rates were faster than tide gauges have recorded since the early 1990s. Rapid rates recorded by tide gauges occurred somewhat later. At Sydney the mean rate of sea-level rise was $4.0 \pm 0.8 \mathrm{~mm} / \mathrm{yr}$ from 1940 to 1960 and at Auckland $3.8 \pm 0.7 \mathrm{~mm} / \mathrm{yr}$ from 1930 to 1960 . Between 1915 and 1960, sea level at Fremantle rose on average by $2.2 \pm 0.5 \mathrm{~mm} / \mathrm{yr}$. A deceleration of sea-level rise around 1960 is also manifested in these tide-gauge records (PSMSL, 2011; Watson, 2011). A compilation of west Pacific tide-gauge records displays a rapid increase in the rate of sea-level rise during the 1930s and 1940s, reaching a maximum of $5 \mathrm{~mm} / \mathrm{yr}$ in the 1950s (Jevrejeva et al., 2006), followed by stable or falling sea levels (Woodworth et al., 2009). Similarly, Church et al. (2004) observed low rates of sea-level rise relative to the global mean in the western Pacific and eastern Indian Ocean during the latter half of the 20th century. The sea-level reconstruction for Tasmania lacks the resolution that is required for a direct comparison with the local tide-gauge records at Spring Bay and Burnie for the past two decades.

The Tasmania sea-level reconstruction is similar to that of southern New Zealand (Gehrels et al., 2008), except for the 1930s and 1940s when sea level in New Zealand appears to have been slightly lower (Fig. 5c). However, stable sea levels during the 19th century and during the period from the 1960s to the 1980s are features common to both records. In New Zealand there is a lack of data in the early 1900s, which complicates the exact dating of the onset of rapid sea-level rise, but available data are compatible with the record from Tasmania.

In Table 3 we compare the magnitudes of the 20th century increase in the rate of sea-level change in Tasmania and New Zealand with similar data from North Atlantic proxy records and long tidegauge records. We note that the magnitude of the rate change is higher in the Southern Hemisphere records. Furthermore, the spatial pattern also shows an increase in the magnitude of the change from north to south in the North Atlantic. Such a pattern can be explained by a sea-level fingerprint of Northern Hemisphere sources, primarily the Greenland Ice Sheet, but also mountain glaciers in Alaska, western North America and the Canadian Arctic. The Greenland Ice Sheet, for example, experienced a shift from positive to negative mass balance in the 1920s (Wake et al., 2009). The contribution of Patagonian glaciers, on the other hand, was negligible (Glasser et al., 2011). The fingerprint is produced by gravitational, elastic and rotational effects of mass redistribution following ice melt (Mitrovica et al., 2001). Although there are many processes that can obscure such a spatial pattern, including steric (Wake et al., 2006) and ocean dynamical changes (Stammer, 2008), it has recently been demonstrated that sea-level fingerprints are detectable if the melt rate is sufficiently large (Kopp et al., 2010). The hypothesis that northern hemisphere ice masses were the main contributor to global sea-level rise in the early part of the 20th century requires further testing, for example by obtaining new proxy sea-level records from other sites in the Southern Hemisphere (e.g., southern South America, South Africa) and by estimating steric and ocean dynamical effects from before the instrumental period using a modelling approach.

\section{Conclusions}

Relative sea-level change in eastern Tasmania was reconstructed from analyses of salt-marsh and estuarine deposits. The record shows that sea-level was stable and slightly lower than present during the middle and late Holocene and during the 19th century. Starting between 1880 and 1900, sea level rose at about $4 \mathrm{~mm} / \mathrm{yr}$ until the 1950s after which sea-level rise significantly slowed down. Maximum rates of sealevel rise were achieved in the $1910 \mathrm{~s}(4.5 \pm 2.5 \mathrm{~mm} / \mathrm{yr})$. The reconstructed 20th century average rate of relative sea-level rise in eastern Tasmania is $1.5 \pm 0.4 \mathrm{~mm} / \mathrm{yr}$. The rapid early 20th century sea-level change documented in eastern Tasmania also occurred in southeastern New Zealand. The magnitude of the change observed in the records from Tasmania and New Zealand is greater than in the North Atlantic and is consistent with a spatial pattern that suggests that Northern Hemisphere melt sources contributed significantly to global sea-level rise in the early 20th century.

Supplementary materials related to this article can be found online at doi:10.1016/j.epsl.2011.08.046.

\section{Acknowledgements}

For help in the field we thank Nick Callow, Sasha Colecutt, Richard Coleman, Maria Gehrels, Hugh Grenfell, Nick Bowden, Brigid Morrison and Kelly O' Loughlin. Kurt Lambeck provided GIA model sea-level estimates. Jamie Quinn drafted diagrams. Three anonymous reviewers provided constructive comments. This paper is a contribution to PALSEA/IMAGES, to IGCP Project 588 ("Preparing for Coastal Change") and to the INQUA Commission on Coastal and Marine Processes.

Table 3

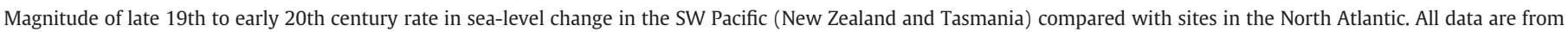
proxy records, except the PSMSL (2011) records which are from tide gauges.

\begin{tabular}{|c|c|c|c|c|c|c|}
\hline Location & Latitude & Inflexion & $\begin{array}{l}\text { Pre-inflexion } \\
(\mathrm{mm} / \mathrm{yr})\end{array}$ & $\begin{array}{l}\text { Post-inflexion } \\
(\mathrm{mm} / \mathrm{yr})\end{array}$ & $\begin{array}{l}\text { Difference } \\
(\mathrm{mm} / \mathrm{yr})\end{array}$ & Reference \\
\hline \multicolumn{7}{|l|}{ SW Pacific } \\
\hline New Zealand & $46^{\circ} 29^{\prime} \mathrm{S}$ & $1900-1940$ & 0.3 & 2.8 & 2.5 & Gehrels et al. (2008) \\
\hline \multirow[t]{2}{*}{ Tasmania } & $42^{\circ} 20^{\prime} \mathrm{S}$ & $1880-1910$ & 0.9 & $4.2(1900-1950)$ & 3.3 & This study \\
\hline & & & & $0.7(1950-2000)$ & & \\
\hline \multicolumn{7}{|l|}{ NW Atlantic } \\
\hline Nova Scotia & $44^{\circ} 44^{\prime} \mathrm{N}$ & $1900-1920$ & 1.6 & 3.2 & 1.6 & Gehrels et al. (2005) \\
\hline Connecticut & $41^{\circ} 20^{\prime} \mathrm{N}$ & $1850-1900$ & 1.0 & 2.8 & 1.8 & Donnelly et al. (2004) \\
\hline N Carolina & $35^{\circ} 53^{\prime} \mathrm{N}$ & 1879-1915 & 0.8 & 3.0 & 2.2 & Kemp et al. (2009) \\
\hline \multicolumn{7}{|l|}{ NE Atlantic } \\
\hline N Spain & $30^{\circ} 23^{\prime} \mathrm{N}$ & $1880-1920$ & 0.3 & 1.9 & 1.6 & Leorri et al. (2008) \\
\hline Brest & $48^{\circ} 23^{\prime} \mathrm{N}$ & 1900 & 0.3 & 1.4 & 1.1 & PSMSL (2011) \\
\hline Swinoujscie & $53^{\circ} 55^{\prime} \mathrm{N}$ & 1900 & 0.2 & 1.2 & 1.0 & PSMSL (2011) \\
\hline Stockholm & $59^{\circ} 19^{\prime} \mathrm{N}$ & 1900 & -0.5 & -0.4 & 0.1 & PSMSL (2011) \\
\hline
\end{tabular}




\section{References}

APSA Members, 2008. The Australasian Pollen and Spore Atlas V 1.0. Australian National University, Canberra, Australia. http://apsa.anu.edu.au. 2008.

Arnaud, F., Magand, O., Chapron, E., Bertrand, S., Boës, X., Charlet, F., Mélières, M.-A., 2006. Radionuclide dating $\left({ }^{210} \mathrm{~Pb},{ }^{137} \mathrm{Cs},{ }^{241} \mathrm{Am}\right)$ of recent lake sediments in a highly active geodynamic setting (Lakes Puyehue and Icalma - Chilean Lake District). Sci. Total. Environ. 366, 837-850.

Bindoff, N.L., Willebrand, J., Artale, V., Cazenave, A., Gregory, J., Gulev, S., Hanawa, K., Le Quéré, C., Levitus, S., Nojiri, Y., Shum, C.K., Talley, L.D., Unnikrishnan, A., 2007. Observations: oceanic climate change and sea level. In: Solomon, S., Qin, D., Manning, M., Chen, Z., Marquis, M., Averyt, K.B., Tignor, M., Miller, H.L. (Eds.), Climate Change 2007: The Physical Science Basis. : Contribution of Working Group I to the Fourth Assessment Report of the Intergovernmental Panel on Climate Change. Cambridge University Press, Cambridge, United Kingdom and New York, NY, USA, pp. 385-432.

Blaauw, M., Christen, J.A., 2011. Flexible paleoclimate age-depth models using an autoregressive gamma process. Bayesian Analysis 6, 457-474.

Bryant, E.A., 1992. Last interglacial and Holocene trends in sea-level maxima around Australia: implications for modern rates. Mar. Geol. 108, 209-217.

Callard, S.L., Gehrels, W.R., Morrison, B.V., Grenfell, H.R., 2011. Suitability of salt-marsh foraminifera as proxy indicators of sea level in Tasmania. Mar. Micropaleontol. 79, 121-131.

Church, J.A., White, N.J., Coleman, R., Lambeck, K., Mitrovica, J.X., 2004. Estimates of the regional distribution of sea level rise over the 1950-2000 period. J. Clim. 17, 2609-2624.

Donnelly, J.P., Cleary, P., Newby, P., Ettinger, R., 2004. Coupling instrumental and geological records of sea-level change: evidence from southern New England of an increase in the rate of sea-level rise in the $19^{\text {th }}$ century. Geophys. Res. Lett. 30. doi:10.1029/ 2003 GL017801.

Forsyth, S.M., Gulline, A.B., 1979. Explanatory Report, Oatlands Sheet SK-55/6, Geological Atlas 1: 250000 Series. Geological Survey of Tasmania. Tasmania Department of Mines, Hobart.

Gehrels, W.R., 1999. Middle and late Holocene sea-level changes in eastern Maine reconstructed from foraminiferal saltmarsh stratigraphy and AMS $14 \mathrm{C}$ dates on basal peat. Quat. Res. 52, 350-359.

Gehrels, W.R., 2002. Intertidal foraminifera as palaeoenvironmental indicators. In: Haslett, S.K. (Ed.), Quaternary Environmental Micropalaeontology. Arnold Publishers, pp. 91-114. Chapter 5.

Gehrels, W.R., Milne, G.A., Kirby, J.R., Patterson, R.T., Belknap, D.F., 2004. Late Holocene sea-level changes and isostatic crustal movements in Atlantic Canada. Quat. Int. 120, 79-89.

Gehrels, W.R., Kirby, J.R., Prokoph, A., Newnham, R.M., Achterberg, E.P., Evans, E.H., Black, S., Scott, D.B., 2005. Onset of recent rapid sea-level rise in the western Atlantic Ocean. Quat. Sci. Rev. 24, 2083-2100.

Gehrels, W.R., Marshall, W.A., Gehrels, M.J., Larsen, G., Kirby, J.R., Eiriksson, J., Heinemeier, J., Shimmield, T., 2006. Rapid sea-level rise in the North Atlantic Ocean since the first half of the 19th century. Holocene 16, 948-964.

Gehrels, W.R., Hayward, B.W., Newnham, R.M., Southall, K.E., 2008. A 20th century sealevel acceleration in New Zealand. Geophys. Res. Lett. 35, L02717. doi:10.1029/ 2007GL032632.

Gibb, J.G., 1986. A New Zealand regional Holocene eustatic sea-level curve and its application to determination of vertical tectonic movement. R. Soc. N. Z. Bull. 24, 377-395.

Gill, E.D., 1983. Australian sea levels in the last 15000 years - Victoria, S.E. Australia. In: Hopley, D. (Ed.), Australian Sea Levels in the Last 15,000 Years: A review. James Cook University of North Queensland, Department of Geography Monograph Series, Occasional Paper No. 3. James Cook University of North Queensland, Department of Geography, Townsville, Queensland, Australia, pp. 59-63.

Glasser, N.F., Harrison, S., Jansson, K.N., Anderson, K., Cowley, A., 2011. Global sea-level contribution from the Patagonian Ice Fields since the Little Ice Age maximum. Nat. Geosci. 4, 303-307. doi:10.1038/ngeo1122.

Harle, K.J., Britton, K., Heijnis, H., Zawadski, A., Jenkinson, A.V., 2002. Mud, mines and rainforest: a short history of human impact in western Tasmania, using pollen, trace metals and lead-210. Aust. J. Bot. 50, 481-497.

Hedge and Kriwoken, 2000. Evidence for the effects of Spartina anglica invasion on benthic macrofauna in Little Swanport estuary, Tasmania. Austral Ecol. 25, 150-159.

Hua, Q., Barnetti, M., 2004. Review of tropospheric bomb ${ }^{14} \mathrm{C}$ data for carbon cycle modelling and age calibration purposes. Radiocarbon 46, 1273-1298.

Hughen, K.A., Baillie, M.G.L., Bard, E., Beck, J.W., Bertrand, C.J.H., Blackwell, P.G., Buck, C.E., Burr, G.S., Cutler, K.B., Damon, P.E., Edwards, R.L., Fairbanks, R.G., Friedrich, M., Guilderson, T.P., Kromer, B., McCormac, G., Manning, S., Bronk Ramsey, C., Reimer, P.J., Reimer, R.W., Remmele, S., Southon, J.R., Stuiver, M., Talamo, S., Taylor, F.W., van der Plicht, J., Weyhenmeyer, C.E., 2004. Marine04 marine radiocarbon age calibration, 0-26 cal kyr BP. Radiocarbon 46, 1059-1086.

Hunter, J., Coleman, R., Pugh, D., 2003. The sea level at Port Arthur, Tasmania, from 1841 to the present. Geophys. Res. Lett. 30. doi:10.1029/2002GL016813.

Jevrejeva, S., Grinsted, A., Moore, J.C., Holgate, S., 2006. Nonlinear trends and multiyear cycles in sea level records. J. Geophys. Res. 111, C09012. doi:10.1029/2005JC003229.

Kemp, A.C., Horton, B.P., Culver, S.J., Corbett, D.R., van de Plassche, O., Gehrels, W.R., Douglas, B.C., Parnell, A.C., 2009. Timing and magnitude of recent accelerated sea-level rise (North Carolina, United States). Geology 37, 1035-1038.

Kopp, R.E., Mitrovica, J.X., Griffies, S.M., Yin, J., Hay, C.C., Stouffer, R.J., 2010. The impact of Greenland melt on local sea levels: a partially coupled analysis of dynamic and static equilibrium effects in idealized water-hosing experiments. Clim. Change 103, 619-625.
Lambeck, K., Nakada, M., 1990. Late Pleistocene and Holocene sea-level change along the Australian coast. Palaeogeogr. Palaeoclimatol. Palaeoecol. 89, 143-176.

Leorri, E., Horton, B.P., Cearreta, A., 2008. Development of a foraminifera-based transfer function in the Basque marshes, N. Spain: implications for sea-level studies in the Bay of Biscay. Mar. Geol. 251, 60-74.

Macphail, M., Hope, G.S., 2003. Natural Histories: an illustrated guide to fossil pollen and spores preserved in swamps and mires of the Southern Highlands, NSW. PalaeoWorks Technical Report 1. Australian National University, Canberra, Australia.

Marshall, W.A., Gehrels, W.R., Garnett, M.H., Freeman, S.P.H.T., Maden, C., Xu, S., 2007 The use of 'bomb spike' calibration and high-precision AMS ${ }^{14} \mathrm{C}$ analyses to date salt-marsh sediments deposited during the past three centuries. Quat. Res. 68, 325-337.

Mault, A., 1890. On some tide observations at Hobart during February and March, 1889. Papers and Proceedings of the Royal Society of Tasmania for 1889, pp. 8-12.

McCormac, F.G., Hogg, A.G., Blackwell, P.G., Buck, C.E., Higham, T.F.G., Reimer, P.J., 2004. SHCal04 Southern Hemisphere Calibration $0-1000$ cal BP. Radiocarbon 46 1087-1092.

Mitrovica, J.X., Tamisiea, M.E., Davis, J.L., Milne, G.A., 2001. Recent mass balance of polar ice sheets inferred from patterns of global sea-level change. Nature 409, 1026-1029.

Mudd, G.M., 2009. The sustainability of mining in Australia: key production trends and their environmental implications for the future. Research Report RR5, Department of Civil Engineering, Monash University and Mineral Policy Institute. revised April 2009, 269 pp.

Murray-Wallace, C.V., Goede, A., 1991. Aminostratigraphy and electron spin resonance studies of late Quaternary sea level change and coastal neotectonics in Tasmania. Z. Geomorphol. N.F. 35, 129-149.

PSMSL (Permanent Service for Mean Sea Level), 2011. www.psmsl.org2011.

Pugh, D., Hunter, R., Coleman, R., Watson, C., 2002. A comparison of historical and recent sea level measurements at Port Arthur, Tasmania. Int. Hydrographic Rev. 3, 27-46.

Reimer, P.J., Brown, T.A., Reimer, R.W., 2004. Discussion: reporting and calibration of post-bomb ${ }^{14} \mathrm{C}$ data. Radiocarbon 46, 1299-1304.

Reimer, P.J., Baillie, M.G.L., Bard, E., Bayliss, A., Beck, J.W., Blackwell, P.G., Bronk Ramsey, C., Buck, C.E., Burr, G.S., Edwards, R.L., Friedrich, M., Grootes, P.M., Guilderson, T.P. Hajdas, I., Heaton, T.J., Hogg, A.G., Hughen, K.A., Kaiser, K.F., Kromer, B., McCormac F.G., Manning, S.W., Reimer, R.W., Richards, D.A., Southon, J.R., Talamo, S., Turney, C.S.M., van der Plicht, J., Weyhenmeyer, C.E., 2009. IntCal09 and Marine09 radiocarbon age calibration curves, $0-50,000$ years cal BP. Radiocarbon 51, 1111-1150.

Rogers, B., 1991. Interpretation of an 1830s salt works site on the Little Swanport River. Aust. Hist. Archaeology 9, 49-55.

Roy, P.S., Williams, R.J., Jones, A.R., Yassini, I., Gibbs, P.J., Coates, B., West, R.J., Scanes, P.R., Hudson, J.P., Nichol, S., 2001. Structure and function of south-east Australian estuaries. Estuar. Coast. Shelf Sci. 53, 351-384.

Seen, A., Townsend, A., Atkinson, B., Ellison, J., Harrison, J., Heijnis, H., 2004. Determining the history and sources of contaminants in sediments in the Tamar Estuary Tasmania, using $210 \mathrm{~Pb}$ dating and stable $\mathrm{Pb}$ isotope analysis. Environ. Chem. 1, 49-54.

Shennan, I., Horton, B.P., 2002. Relative sea-level changes and crustal movements of the UK. J. Quat. Sci. 16, 511-526.

Southall, K.E., Gehrels, W.R., Hayward, B.C., 2006. Foraminifera in a New Zealand salt marsh and their suitability as sea-level indicators. Mar. Micropaleontol. 60, 167-179.

Stammer, D., 2008. Response of the global ocean to Greenland and Antarctic ice melting. J. Geophys. Res. 113, C06022. doi:10.1029/2006JC004079.

Stuiver, M., Polach, H.A., 1977. Reporting of ${ }^{14} \mathrm{C}$ data. Radiocarbon 19, 355-363.

Vallelonga, P., Van de Velde, K., Candelone, J.-P., Morgan, V.I., Boutron, C.F., Rosman, K.J.R., 2002. The lead pollution history of Law Dome, Antarctica, from isotopic measurements on ice cores: 1500 AD to 1989 AD. Earth Planet. Sci. Lett. 204, 291-306.

Van de Velde, K., Vallelonga, P., Candelone, J.-P., Rosman, K.J.R., Gaspari, V., Cozzi, G. Barbante, C., Udisti, R., Cescon, P., Boutron, C.F., 2005. Pb isotope record over one century in snow from Victoria Land, Antarctica. Earth Planet. Sci. Lett. 232, 95-108

van der Kaars, W.A., 1991. Palynology of eastern Indonesian piston-cores: a late Quaternary vegetational and climatic record for Australasia. Palaeogeogr. Palaeoclimatol. Palaeoecol. 85, 239-302.

Wake, L., Milne, G., Leuliette, E., 2006. 20th century sea-level change along the eastern US: unravelling the contributions from steric changes, Greenland ice sheet mass balance and Late Pleistocene glacial loading. Earth Planet. Sci. Lett. 250, 572-580.

Wake, L.M., Huybrechts, P., Box, J.E., Hanna, E., Janssens, I., Milne, G.A., 2009. Surface mass-balance changes of the Greenland ice sheet since 1866. Ann. Glaciol. 50, 178-184.

Watson, P.J., 2011. Is there evidence yet of acceleration in mean sea level rise around mainland Australia? J. Coast. Res. 27, 368-377.

Wolff, E.W., Suttie, E.D., 1994. Antarctic snow record of southern hemisphere lead pollution. Geophys. Res. Lett. 21, 781-784.

Woodworth, P.L., White, N.J., Jevrejeva, S., Holgate, S.J., Church, J.A., Gehrels, W.R., 2009. Evidence for the accelerations of sea level on multi-decade and century timescales. Int. J. Climatol. 29, 777-789.

Yassini, I., Jones, B.G., 1995. Foraminiferida and Ostracoda from Estuarine and Shelf Environments on the Southeastern Coast of Australia. University of Wollongong Press, Wollongong, Australia. 484 pp. 